\title{
Correlations between glacier properties: finding appropriate parameters for global glacier monitoring
}

\author{
Mark B. Dyurgerov, David B. Bahr \\ Institute of Arctic and Alpine Research, Campus Box 450, University of Colorado-Boulder, Boulder, Colorado 80309-0450, U.S.A.
}

\begin{abstract}
To develop new strategies for global mass-balance monitoring, data for the period 1961-90 have been compiled for 80 glaciers with a variety of mass-balance and morphological parameters. This dataset is significantly larger than that used in previous studies. This allows us to check the mass-balance data for both strong and weak correlations with different glacier parameters. In many cases, the strong correlations suggest new approaches to monitoring glaciers on a global scale. For example, the mass balance at the terminus is strongly correlated with the difference in elevation between the terminus and the glacier's mean elevation. These easily measured parameters could be particularly useful in assessing maximum ablation and meltwater potential based on altitudes derived from maps and photographs. Good correlations also exist between differences in massbalance parameters (e.g. net balance minus terminus balance) and several other morphological properties (e.g. elevation range and length). Equally important, the weak correlations demonstrate that some relationships commonly used on individual glaciers are not appropriate when considering global monitoring strategies. For example, the correlation between net mass balance and terminus balance is very poor. Likewise, the correlation between the net mass balance and equilibrium-line altitude is weak, and the correlation between the net mass balance and activity index is almost non-existent. This suggests that although these climatically sensitive parameters may be closely related on individual glaciers, these same relationships are not reliable as tools for monitoring glaciers on a global scale.
\end{abstract}

\section{INTRODUCTION}

Glaciers act as reservoirs, storing and releasing water with changes in local, regional and global climate. As such, tracking a glacier's change in shape and volume with time can provide valuable information about current climatic conditions and the response to previous changes in climate on time-scales of years to centuries (e.g. Meirr, 1965; Jóhannesson and others, 1989). The classic link between a glacier and its climate has been the net mass balance (e.g. Meier, 1965), but there are other approaches and key components to monitoring glacier fluctuations. Some parameters used for monitoring, such as glacier tongue position, length, area and elevation, are easy to measure or easy to determine from maps, air photos and satellite images. Many other characteristics, such as the activity index, mass balance and their associated components, are not as easy to determine. Measuring these parameters can be an expensive and laborious task (Østrem and Brugman, 1991).

Several alternative approaches for regional and global glacier monitoring have been developed recently. The theoretical background and some practical recommendations for these new techniques are given in Krenke and Menshutin (1987), Dyurgerov (1988, 1993), Jóhannesson and others (1989), Meier (1993), Haeberli (1995) and Fountain and others (1997). However, many of these new techniques are based on studies using small datasets or even modeled results. More appropriate monitoring strategies could be devised by using a worldwide compilation of all the available data on glacier lengths, areas, activity indices, mass balances, and so forth. Towards this goal, we have used a substantially larger dataset to analyze the relations between a number of commonly monitored characteristics of glaciers: surface area $(S)$, length $(x)$, maximum elevation ( $Z_{\text {up }}$, at the glacier head), mean elevation $\left(Z_{\mathrm{m}}\right)$, minimum elevation $\left(Z_{\mathrm{t}}\right.$, at the terminus), equilibrium-line altitude (ELA), activity index $(E)$, net or annual mass balances $\left(b_{\mathrm{n}}\right)$, and mass balances at the glacier's tongue $\left(b_{\mathrm{t}}\right)$ and head $\left(b_{\text {up }}\right)$. The data for this analysis have been compiled primarily from volumes of Fluctuations of Glaciers (Kasser, 1973; Müller, 1977; Haeberli, 1985; Haeberli and Müller, 1988; Haeberli and Hoelzle, 1993; we refer to them as FOG, 1973, 1977, 1985, 1988, 1993), from Glacier Mass Balance Bulletins (Haeberli and Herren, 1991; Haeberli and others, 1993, 1994, 1996; abbreviated $G M B, 1991,1993,1994,1996)$ and from many other published and unpublished sources with data spanning the period 1961-90 (for details, see Dyurgerov and Meier, 1997).

Special attention is focused here on the terminus balance, $b_{\mathrm{t}}$. This is because $b_{\mathrm{t}}$ may be a key parameter in studies of the response time of glaciers to climate change (Jóhannesson and others, 1989). It has also been suggested that measurements of the mass balance at the terminus and at one or two stakes in the vicinity of the ELA may provide a reasonable estimate of the mass balance of an entire glacier, $b_{\mathrm{n}}$ (Haeberli, 1995). This has been recommended as part of a future strategy for mass-balance measurements (Haeberli, 1995). However, even though $b_{\mathrm{t}}$ is easier to measure than $b_{\mathrm{n}}$, there are few terminus balance data available at present. To estimate $b_{\mathrm{t}}$, measurements of mass balance vs altitude are 
needed. Of all the glaciers with mass-balance measurements (around 260; see Dyurgerov and Meier, 1997) we found only 80 glaciers worldwide with published data on annual balance vs altitude. Thus, our study has been bounded by this sample (Table 1). (To facilitate future studies, we strongly encourage the publication of annual, winter and summer balance profiles in appropriate media (e.g. issues of $G M B$ ). These data will have already been collected by anyone measuring net mass balances.)

In the following sections we divide the 80 glaciers into five subsamples based on their general morphological characteristics (e.g. valley glacier vs mountain ice cap). For each subsample, a variety of variables which could be used for monitoring glaciers $\left(S, x, Z_{\mathrm{up}}, Z_{\mathrm{m}}, Z_{\mathrm{t}}\right.$, ELA, $E, b_{\mathrm{n}}, b_{\mathrm{t}}$ and $\left.b_{\mathrm{up}}\right)$ are correlated with each other. Based on these correlations (which come from a comparatively large possible selection), we suggest what parameters and combinations of parameters might be most useful in monitoring the response of glaciers to changes in climate.

\section{DATA PROCESSING}

Country codes and geographical locations have been taken from FOG volumes without changes. In order to reduce errors, the periods of mass-balance study, the elevations $\left(Z_{\text {up }}, Z_{\mathrm{m}}, Z_{\mathrm{t}}\right)$ and the area $(S)$ have been taken from $F O G \mathrm{~s}$ and compared with primary sources when possible. The mean specific mass balance $\left(b_{n}\right)$ of a mountain glacier has been calculated as a function of altitude:

$$
b_{\mathrm{n}}=\left[\sum b\left(h_{i}\right) s\left(h_{i}\right)\right] / S .
$$

The sum is taken over the entire glacier, where $b$ is the measured or calculated mass balance centered in altitude increments $h_{i}$ (the index $i$ refers to the altitude range), and where $s\left(h_{i}\right)$ is the area-altitude distribution. The same approach has been used to calculate winter and summer balances $\left(b_{\mathrm{w}}\right.$, and $b_{\mathrm{s}}$ ). Data for these have been compiled from $F O G \mathrm{~s}$ and from other sources of original information (see sources in Table 1). The data on vertical variations in annual balance have been used to estimate $b_{\text {up }}$ and $b_{\mathrm{t}}$. We also recalculated $b_{\mathrm{n}}$ from the seasonal mass-balance components $\left(b_{\mathrm{n}}=\right.$ $b_{\mathrm{w}}-b_{\mathrm{s}}$ ) in order to identify and, where possible, correct errors in previous publications. Thus, the data presented in Table 1, all of which are averages over the period of record shown in column $\mathrm{G}$, are somewhat different, in many cases, from those published in the FOGs.

For many glaciers, the curves describing the vertical distribution of annual mass balance have complicated shapes. To estimate these profiles, data for vertical profiles of $b_{n}$ on a given glacier have been averaged through time and approximated by power-law, exponential or logarithmic best-fit curves. From these curves, values for the activity index $E$ and ELA have been determined (see Table 1). For the ELAs we tried to use only directly measured values, but in cases where obvious inconsistencies were found, we substituted approximations from the $b_{\mathrm{n}}$ profiles.

Each glacier was assigned to one of five groups (1-5 in Table 1) depending on their basic type. Group 1 contains 31 mountain or outlet glaciers, usually of simple valley-glacier form, with a single accumulation basin and a single lobe (clean or only partly covered by debris). Group 2 consists of 29 glaciers, similar to group 1, but with two or more separate accumulation basins; these glaciers have more complex shapes and larger surface areas. Group 3 comprises ten cirque glaciers, or other small glaciers with a single accumulation basin and lobe. Group 4 includes six dome-shaped ice fields or ice caps (mountain and subpolar). Group 5 contains four glaciers that calve into sea, a lake or land. We placed these glaciers in a separate group because their length and other morphometric characteristics may be altered by the calving discharge (Meier and Post, 1987).

For consistency, in making this division into five groups we have used the classification scheme and three digit codes) introduced in FOG (see FOG, 1985, p. 100-103 and table A). In reality, the differences between groups 1 and 2 are slight and occasionally ambiguous. Dzhankuat and Marukh glaciers (central and western Caucasus), for example, might have been included in group 1, but following the internationally recognized classification (FOG, 1985, table A), we include them in group 2. Also, although group 5 contains all calving glaciers, the differences between them can be profound. The tongues of some of these glaciers do not calve substantial amounts of ice, or they calve on land rather than in water (e.g. the Rhonegletscher, Griesgletscher and Bridge Glacier). Each of these might have been included in group 1 or 2 . On the other hand, Columbia Glacier (Chugach Mountains, Alaska) in group 5 is a very large but otherwise typical tidewater glacier which loses most of its ice by calving (Meier and Post, 1987). Average properties summarizing each of the five groups are given at the bottom of Table 1 .

Due to the morphological differences which distinguish groups $1-5$, we might expect some pairs of variables to be correlated differently from one group to another. However, correlations between glacier properties are not possible for the small numbers of glaciers in groups 3-5, so an analysis of the differences in correlations between groups is necessarily preliminary (see below). Instead, we have combined the five distinct groups into five different "samples" that each have enough glaciers to derive meaningful correlations between properties. Sample 1 consists of the 31 simple valley glaciers from group 1. Sample 2 contains the 29 compound valley glaciers from group 2. Sample 3 comprises the 60 glaciers of groups 1 and 2 (i.e. all valley glaciers). Sample 4 has 70 glaciers (including groups 1, 2 and 3; or all the valley and cirque glaciers). Sample 5 contains all 80 glaciers.

As expected, the mean surface area and the length are smallest for the simple valley glaciers in sample 1 (Fig. 1). At the same time, $b_{\text {up }}$ and $b_{\mathrm{t}}$ are less positive and more negative, respectively, for sample 1 compared with the other samples (Fig. 2). The elevations $\left(Z_{\mathrm{up}}, Z_{\mathrm{t}}, Z_{\mathrm{m}}\right)$ and the ELA are higher and $E$ is larger in sample 1 than in other samples (Figs 3 and 4 and bottom lines in Table 1). For each of the samples, the next section explores correlations between the various glacier parameters.

\section{RESULTS}

Within a given sample, two properties (such as terminus balance and length) were selected for each glacier. Both linear and power-law correlations were calculated between these two parameters. Similar linear and power-law correlations were determined for all other pairs of parameters commonly used in monitoring glaciers (i.e. the previously mentioned $S, x, Z_{\text {up }}, Z_{\mathrm{m}}, Z_{\mathrm{t}}$, ELA, $E, b_{\mathrm{n}}, b_{\mathrm{t}}$, and $\left.b_{\text {up }}\right)$. Correlations were also performed between each of these parameters and potentially useful combinations of para- 


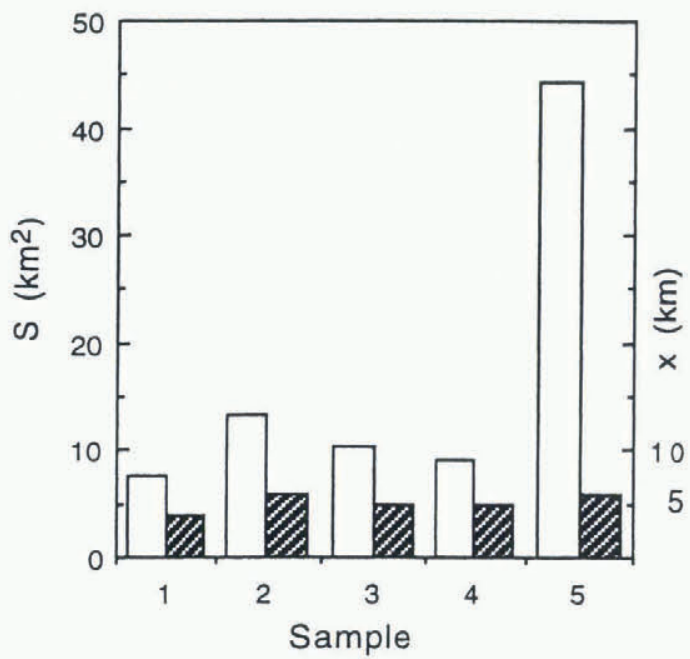

Fig. 1. Histogram of surface area, $S$, and length, $x$ (along center line), averaged by sample.

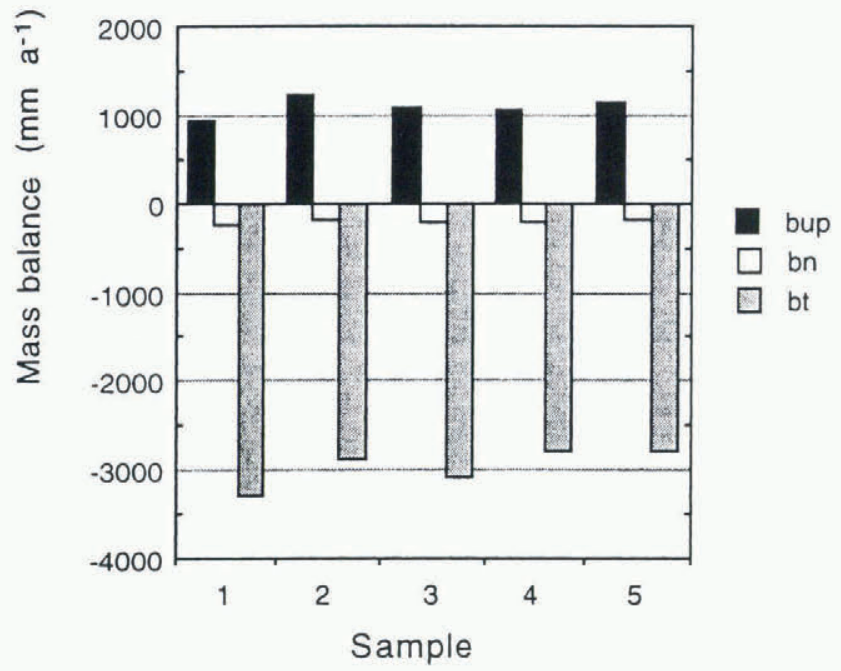

Fig. 2. Histograms of mass balance at the head of the glacier $\left(b_{\mathrm{up}}\right)$, annual or net mass balance $\left(b_{\mathrm{n}}\right)$ and mass balance at the tongue $\left(b_{\mathrm{t}}\right)$, averaged by sample.

meters, such as the total range in elevation $\left(Z_{\text {up }}-Z_{\mathrm{t}}\right)$ and the range in mass balance $\left(b_{\text {up }}-b_{\mathrm{t}}\right)$. We emphasize that all of these correlations are spatial (between many glaciers) and not temporal; each glacier is assigned only one value for each parameter, for example an average ELA and an average net mass balance over the period of observation (Table 1). The correlations for each pair of parameters in each of the five samples are listed in Table 2.

The glaciers in each sample are different in shape and type and reside in many different geographical regions. Thus, correlations between properties apply to all glaciers globally rather than to any individual glacier or mountain range. For example, for individual glaciers, a strong correlation between interannual variations in $b_{\mathrm{n}}$ and the ELA is widely recognized (see, e.g., GMB, 1991, 1993, 1994, 1996). However, for all 80 glaciers considered simultancously (using the temporal mean values of $b_{\mathrm{n}}$ and ELA for each glacier), the correlation between $b_{\mathrm{n}}$ and the ELA is almost non-existent (see Table 2).

For all five samples we have calculated about 130 correlation coefficients $(r)$ for both linear and power-law regressions. In many cases the coefficients of correlation are very weak, but we report them for two reasons. First, our dataset is larger than any other previously analyzed, and it is useful to know that larger datasets do not improve the correlations

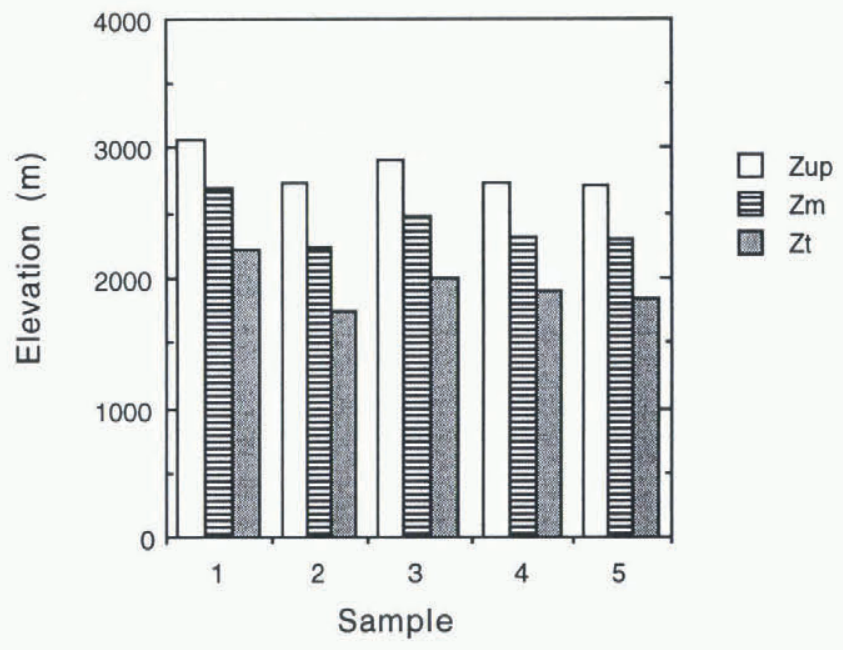

Fig. 3. Glacier minimum $\left(Z_{\mathrm{t}}\right)$ average $\left(Z_{\mathrm{m}}\right)$ and maximum $\left(Z_{\text {up }}\right.$ ) elevations, averaged by sample.

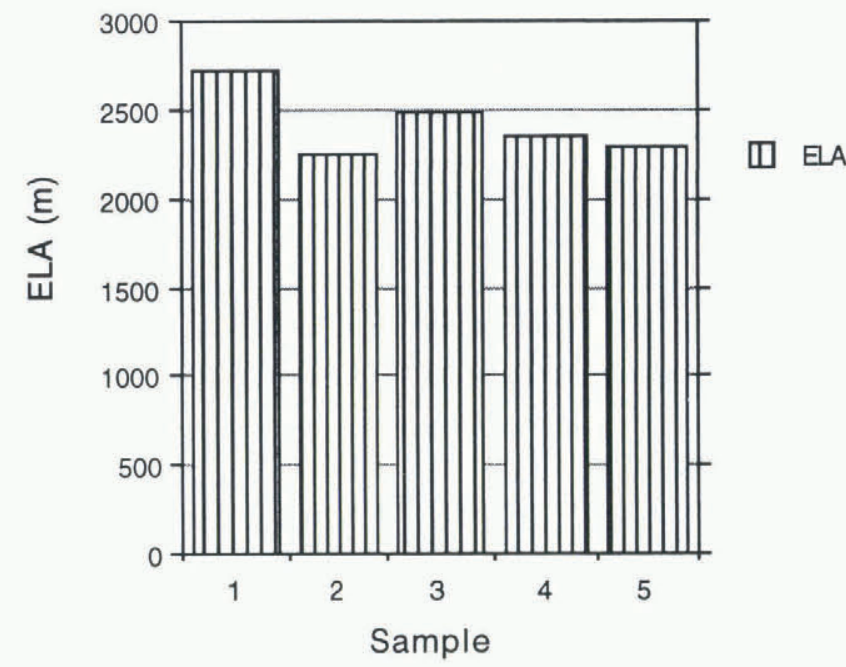

Fig. 4. Equilibrium-line altitude (ELA), averaged by sample.

found in previous analyses with smaller datasets. Second, in addition to recommending strong relationships, we can also note which correlations are not useful for global monitoring programs. Some of these poor correlations may seem obvious, but many others are not. The most important of the possible correlations between combinations of parameters listed in Table 2 are noted here and discussed in the next section.

1. Net or annual specific mass balance (for simplicity we do not distinguish between these two balances). The correlation between $b_{\mathrm{n}}$ and $b_{\mathrm{t}}$ is weak, with $r=-0.4$ for simple valley glaciers and 0.44 for compound valley glaciers. Correlations between $b_{\mathrm{n}}$ and $E$, ELA and all elevations $\left(Z_{\mathrm{m}}, Z_{\mathrm{t}}\right.$, $Z_{\text {up }}$ ) are also very weak. The correlation between $b_{\mathrm{n}}$ and $b_{\text {up }}$ is poor for most samples, although significant $(r=$ -0.72 ) for simple valley glaciers (sample 1). On the other hand, a good linear correlation $(r=0.6-0.8)$ occurs between $\left(b_{\mathrm{n}}-b_{\mathrm{t}}\right)$ and other properties, such as length $x$ and differences in elevation $\left(Z_{\mathrm{m}}-Z_{\mathrm{t}}\right),\left(\right.$ ELA $\left.-Z_{\mathrm{t}}\right)$ and $\left(Z_{\mathrm{up}}-Z_{\mathrm{t}}\right)$.

2. Terminus balance. $b_{\mathrm{t}}$ is well correlated with the length of glaciers, especially in sample $1(r=0.75)$. The correlation coefficient for $b_{\mathrm{t}}$ vs $b_{\text {up }}$ is 0.65 for simple valley glaciers (sample 1) but is very weak for all other samples, especially for relatively large compound glaciers (sample $2 ; r$ $=0.2$. The correlation coefficients for $b_{\mathrm{t}}$ vs $\left(\right.$ ELA $\left.-Z_{\mathrm{t}}\right)$ and $\left(Z_{\mathrm{m}}-Z_{\mathrm{t}}\right)$ are large for all samples $(r=0.7-0.8)$. 


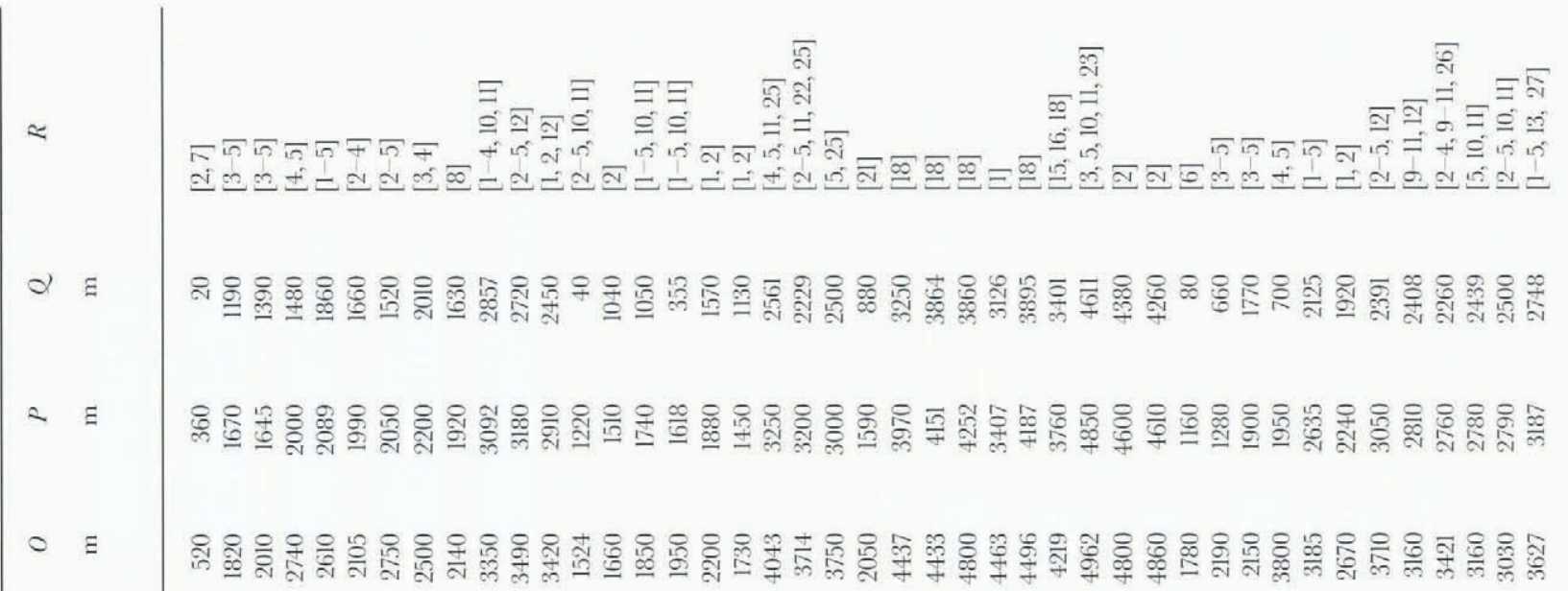

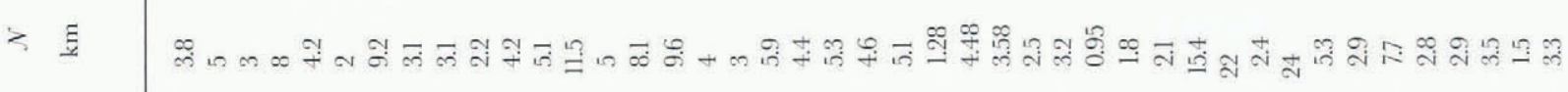

乙 至

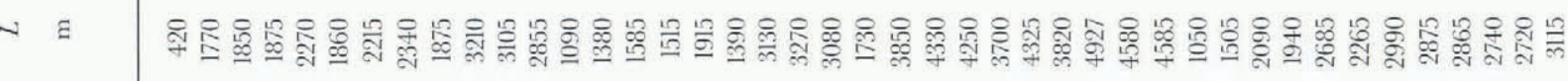

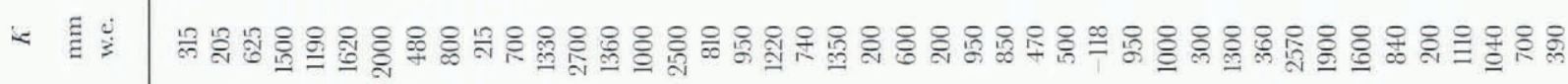

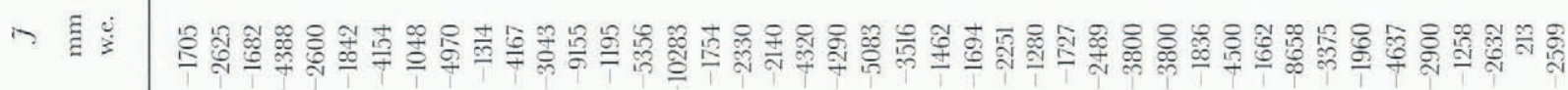

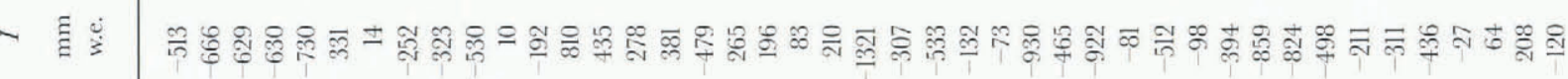

₹ $\quad \alpha+\operatorname{ang} 20 \ln$ in

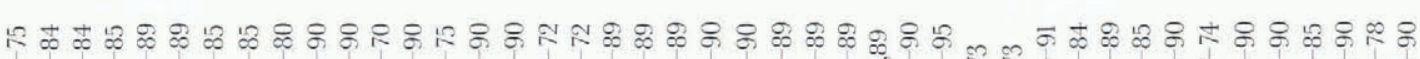

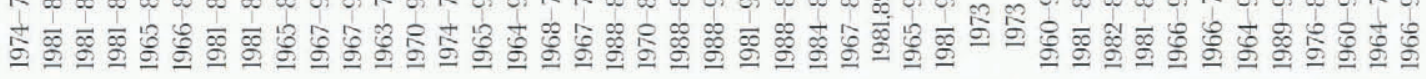

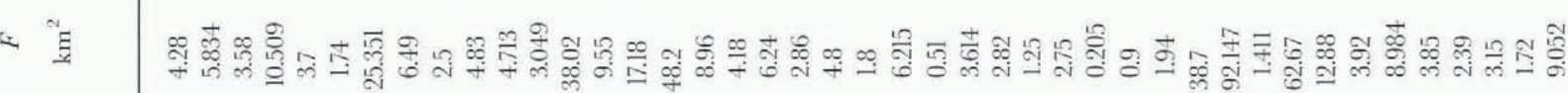

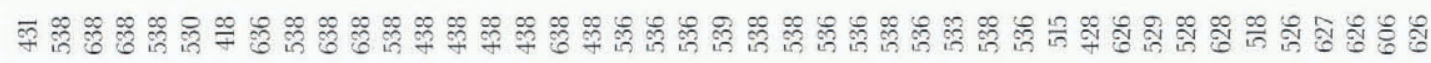

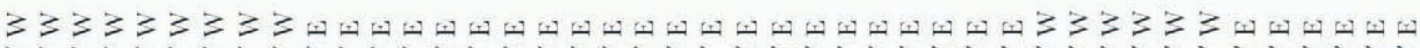

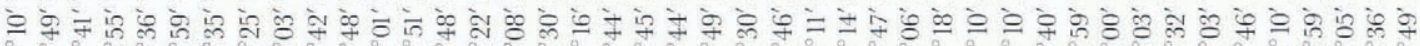

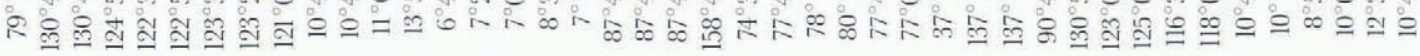

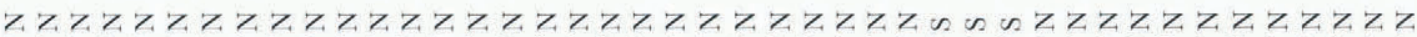

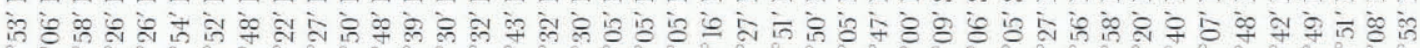

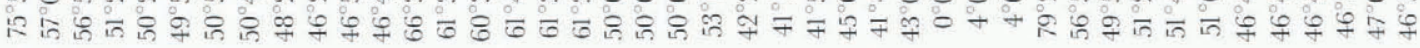

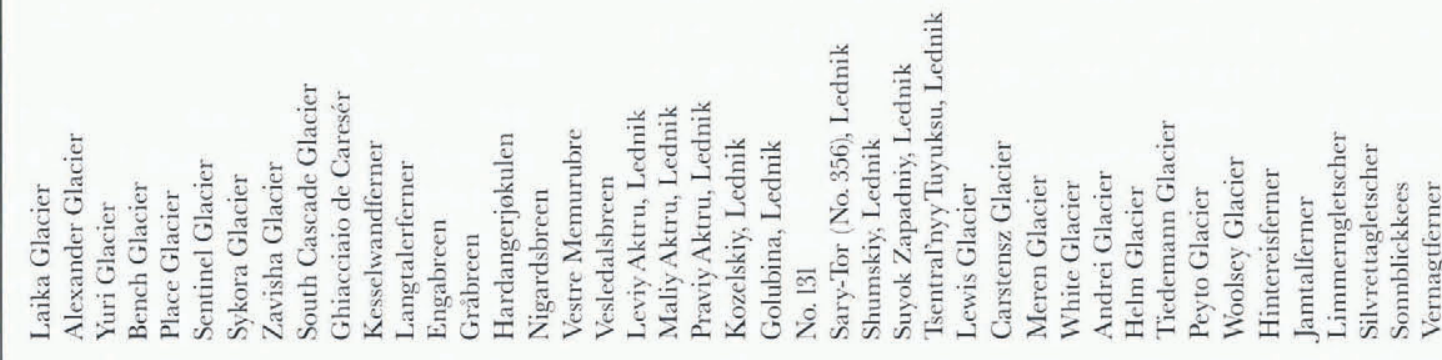




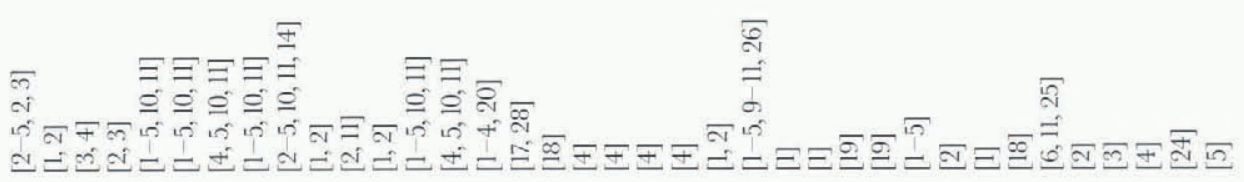

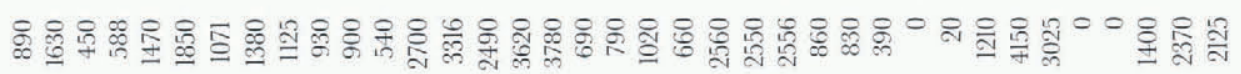

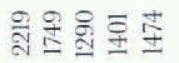

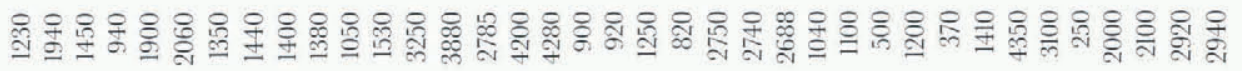

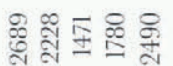

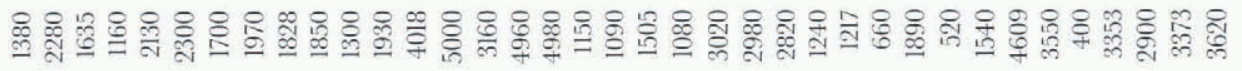

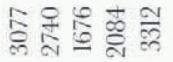

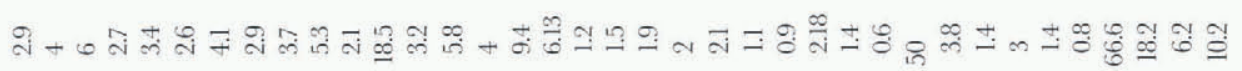

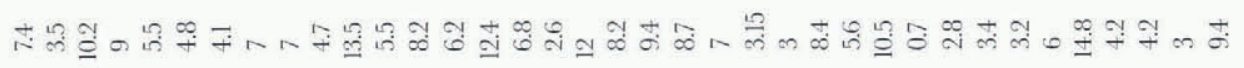

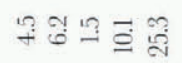

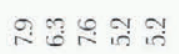

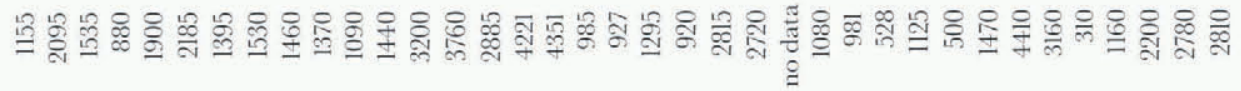

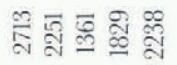

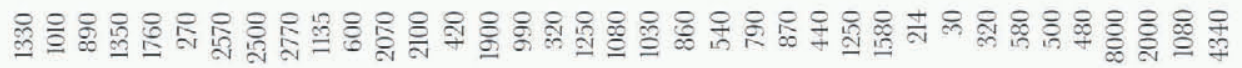

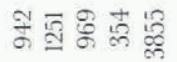

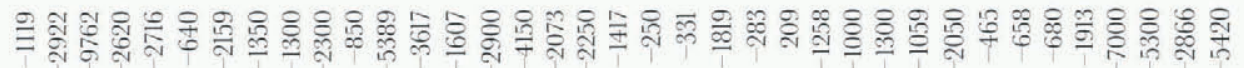

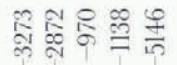

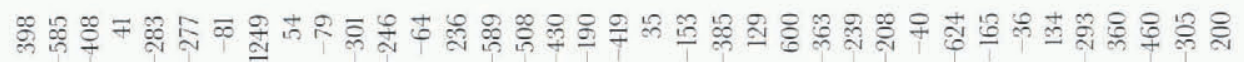

ํํำํㅡำ

$\operatorname{ann}$ ก

$\infty \cong \infty=$

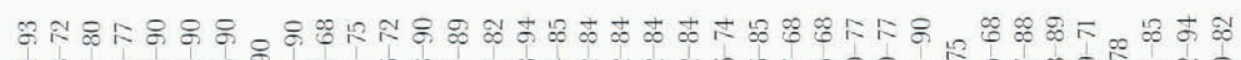

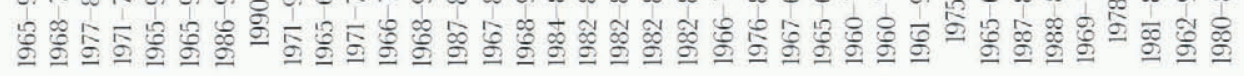

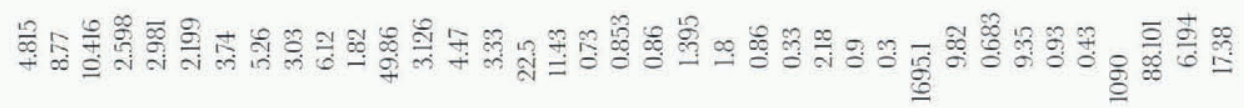

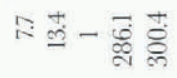

ल ฉㅇ

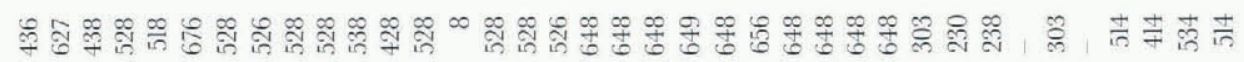

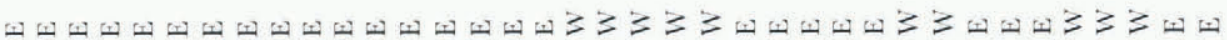

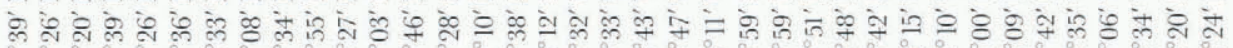

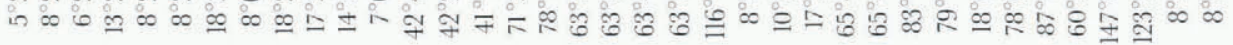

ZZZZZZZZZZZZZZZZZZZZZZZZZZZZZZZZnZZZZ

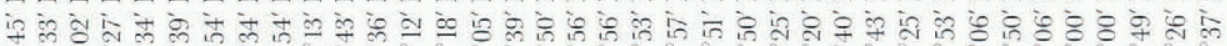

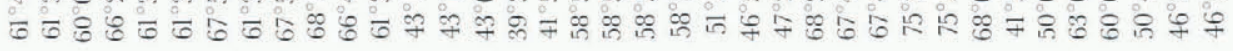

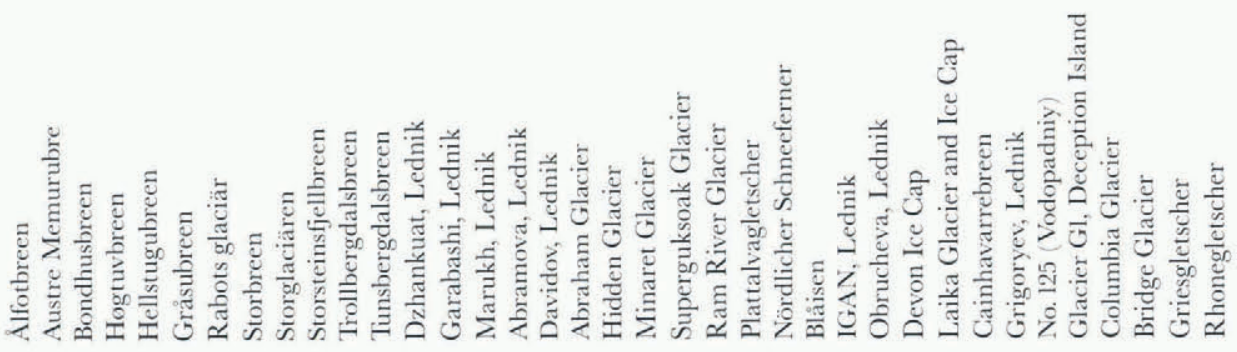


Table 2. Correlation coefficients between glacier properties. In each column the linear correlation coefficients are given first and power-law correlations second

\begin{tabular}{|c|c|c|c|c|c|c|c|c|c|c|c|}
\hline \multirow[b]{2}{*}{1} & \multirow{2}{*}{$\begin{array}{l}\text { Properties } \\
b_{\mathrm{n}} \text { vs } b_{\mathrm{up}}\end{array}$} & \multicolumn{2}{|c|}{ Sample 1} & \multicolumn{2}{|c|}{ Sample 2} & \multicolumn{2}{|c|}{ Sample 3} & \multicolumn{2}{|c|}{ Sample 4} & \multicolumn{2}{|c|}{ Sample.5 } \\
\hline & & -0.72 & -0.45 & -0.20 & -0.10 & -0.46 & -0.29 & -0.42 & -0.30 & -0.38 & -0.18 \\
\hline 2 & $b_{\mathrm{n}}$ vs $b_{\mathrm{t}}$ & -0.40 & -0.01 & 0.44 & 0.32 & -0.02 & 0.16 & 0.04 & 0.20 & 0.01 & 0.32 \\
\hline 3 & $b_{\mathrm{n}} \operatorname{vs} x$ & -0.50 & -0.06 & 0.31 & 0.19 & 0.02 & -0.01 & 0.04 & 0.05 & 0.11 & -0.05 \\
\hline 4 & $b_{n}-b_{\mathrm{t}}$ vs $x$ & 0.76 & 0.59 & 0.58 & 0.60 & 0.54 & 0.58 & 0.58 & 0.64 & 0.41 & 0.60 \\
\hline 5 & $b_{\mathrm{n}}$ vs $Z_{\text {up }}$ & 0.21 & -0.30 & 0.20 & 0.10 & 0.21 & -0.07 & 0.17 & 0.02 & 0.10 & -0.04 \\
\hline 6 & $b_{\mathrm{n}}$ vs $Z_{\text {up }}$ & 0.31 & -0.22 & 0.06 & 0.12 & 0.22 & 0.00 & 0.18 & 0.03 & 0.14 & -0.07 \\
\hline 7 & $b_{\mathrm{n}}$ vs $Z_{\mathrm{m}}$ & 0.23 & -0.27 & 0.16 & 0.09 & 0.21 & -0.04 & 0.17 & 0.04 & 0.11 & -0.02 \\
\hline 8 & $b_{\mathrm{n}} \mathrm{vs}$ ELA & 0.28 & -0.27 & 0.20 & 0.14 & 0.25 & -0.01 & 0.22 & 0.06 & 0.17 & 0.01 \\
\hline 9 & $b_{\mathrm{n}}$ vs $E$ & -0.04 & -0.28 & -0.10 & 0.28 & -0.04 & 0.07 & -0.01 & 0.04 & -0.01 & 0.19 \\
\hline 10 & $b_{\mathrm{n}}-b_{\mathrm{t}}$ vs $Z_{\mathrm{m}}-Z_{\mathrm{t}}$ & 0.83 & 0.71 & 0.74 & 0.62 & 0.78 & 0.65 & 0.81 & 0.69 & 0.75 & 0.69 \\
\hline 11 & $b_{\mathrm{n}}-b_{\mathrm{t}}$ vs ELA $-Z_{\mathrm{t}}$ & 0.69 & 0.42 & 0.78 & 0.60 & 0.72 & 0.51 & 0.75 & 0.58 & 0.72 & 0.59 \\
\hline 12 & $b_{\mathrm{n}}-b_{\mathrm{t}}$ vs $Z_{\mathrm{up}}-Z_{\mathrm{t}}$ & 0.62 & 0.57 & 0.63 & 0.66 & 0.58 & 0.60 & 0.63 & 0.67 & 0.64 & 0.68 \\
\hline 13 & $b_{\mathrm{t}}$ vs $b_{\text {up }}$ & 0.65 & 0.47 & 0.23 & 0.29 & 0.39 & 0.35 & 0.38 & 0.26 & 0.46 & 0.35 \\
\hline 14 & $b_{\mathrm{t}}$ vs $x$ & 0.72 & 0.55 & 0.60 & 0.63 & 0.56 & 0.56 & 0.60 & 0.61 & 0.40 & 0.56 \\
\hline 15 & $b_{\mathrm{t}}$ vs $Z_{\mathrm{t}}$ & -0.40 & -0.29 & -0.25 & -0.12 & -0.31 & -0.21 & -0.21 & -0.10 & -0.21 & -0.09 \\
\hline 16 & $b_{\mathrm{t}}$ vs $Z_{\text {up }}$ & -0.24 & -0.08 & 0.10 & 0.25 & -0.07 & 0.08 & 0.06 & 0.25 & 0.08 & 0.22 \\
\hline 17 & $b_{\mathrm{t}}$ vs $Z_{\mathrm{m}}$ & -0.25 & -0.10 & -0.04 & 0.15 & -0.13 & 0.03 & -0.02 & -0.02 & -0.01 & 0.16 \\
\hline 18 & $b_{\mathrm{t}}$ vs $Z_{\mathrm{m}}-Z_{\mathrm{t}}$ & 0.82 & 0.70 & 0.76 & 0.68 & 0.78 & 0.68 & 0.80 & 0.68 & 0.74 & 0.68 \\
\hline 19 & $b_{\mathrm{t}} \mathrm{vs} E$ & 0.24 & 0.34 & -0.01 & 0.02 & 0.17 & 0.21 & 0.16 & 0.12 & 0.15 & 0.16 \\
\hline 20 & $b_{\mathrm{t}}$ vs ELA & -0.29 & -0.15 & -0.03 & 0.15 & -0.16 & 0.00 & -0.03 & 0.17 & -0.04 & 0.12 \\
\hline 21 & $b_{\mathrm{t}}$ vs ELA $-Z_{\mathrm{t}}$ & 0.71 & 0.51 & 0.81 & 0.72 & 0.76 & 0.62 & 0.78 & 0.65 & 0.74 & 0.65 \\
\hline 22 & $b_{\mathrm{t}}$ vs $b_{\text {up }}-b_{\mathrm{n}}$ & 0.52 & 0.42 & 0.45 & 0.42 & 0.43 & 0.40 & 0.44 & 0.35 & 0.50 & 0.49 \\
\hline 23 & $b_{\text {up }}$ vs $x$ & 0.76 & 0.54 & 0.20 & 0.16 & 0.36 & 0.32 & 0.35 & 0.22 & 0.59 & 0.27 \\
\hline 24 & $b_{\text {up }}$ vs $Z_{\text {up }}$ & -0.28 & 0.01 & -0.20 & -0.20 & -0.26 & -0.10 & -0.23 & -0.13 & -0.02 & 0.14 \\
\hline 25 & $b_{\text {up }}$ vs $Z_{\mathrm{t}}$ & -0.43 & -0.13 & -0.32 & -0.09 & -0.40 & -0.11 & -0.38 & -0.13 & -0.29 & 0.12 \\
\hline 26 & $b_{\text {up }}$ vs $Z_{\mathrm{m}}$ & -0.33 & -0.02 & -0.32 & -0.27 & -0.35 & -0.15 & -0.32 & -0.18 & -0.14 & 0.09 \\
\hline 27 & $b_{\text {up }}$ vs $Z_{\text {up }}-Z_{\mathrm{t}}$ & 0.57 & 0.42 & 0.16 & 0.12 & 0.33 & 0.26 & 0.32 & 0.19 & 0.57 & 0.31 \\
\hline 28 & $b_{\text {up }}$ vs $Z_{\mathrm{m}}-Z_{\mathrm{t}}$ & 0.59 & 0.37 & 0.05 & 0.00 & 0.30 & -0.15 & 0.29 & 0.11 & 0.56 & 0.21 \\
\hline 29 & $b_{\text {up }}$ vs ELA & -0.38 & -0.10 & -0.32 & -0.27 & -0.37 & 0.20 & -0.34 & -0.18 & -0.21 & 0.01 \\
\hline 30 & $b_{\text {up }}$ vs $E$ & 0.08 & 0.11 & 0.17 & 0.40 & 0.06 & 0.21 & 0.07 & 0.21 & 0.03 & 0.27 \\
\hline 31 & $b_{\text {up }}-b_{\mathrm{n}}$ vs $x$ & 0.57 & 0.44 & 0.34 & 0.22 & 0.42 & 0.29 & 0.41 & 0.28 & 0.60 & 0.34 \\
\hline 32 & $b_{\text {up }}-b_{\mathrm{t}}$ vs $x$ & 0.78 & 0.65 & 0.59 & 0.59 & 0.58 & 0.60 & 0.61 & 0.56 & 0.53 & 0.59 \\
\hline 33 & $b_{\text {up }}-b_{\mathrm{t}}$ vs $Z-Z_{\mathrm{t}}$ & 0.82 & 0.73 & 0.68 & 0.46 & 0.75 & 0.57 & 0.77 & 0.62 & 0.78 & 0.62 \\
\hline 34 & $b_{\text {up }}-b_{\mathrm{t}}$ vs $Z_{\text {up }}-Z_{\mathrm{t}}$ & 0.63 & 0.61 & 0.61 & 0.54 & 0.60 & 0.56 & 0.64 & 0.62 & 0.70 & 0.64 \\
\hline 35 & $b_{\text {up }}-b t$ vs ELA $-Z_{\mathrm{t}}$ & 0.69 & 0.47 & 0.73 & 0.57 & 0.71 & 0.53 & 0.73 & 0.62 & 0.70 & 0.57 \\
\hline 36 & $b_{\text {up }}-b_{\mathrm{n}}$ vs $Z_{\text {up }}-Z_{\mathrm{t}}$ & 0.43 & 0.39 & 0.29 & 0.07 & 0.35 & 0.18 & 0.35 & 0.20 & 0.58 & 0.32 \\
\hline 37 & $b_{\mathrm{up}}-b_{\mathrm{n}}$ vs $Z_{\mathrm{m}}-Z_{\mathrm{t}}$ & 0.35 & 0.27 & 0.21 & 0.05 & 0.25 & 0.11 & 0.27 & 0.15 & 0.54 & 0.28 \\
\hline 38 & ELA vs $Z_{\mathrm{m}}$ & 1.00 & 0.99 & 1.00 & 0.99 & 1.00 & 0.99 & 1.00 & 0.99 & 0.99 & 0.99 \\
\hline 39 & ELA vs $Z_{\mathrm{t}}$ & 0.98 & 0.90 & 0.96 & 0.83 & 0.98 & 0.87 & 0.98 & 0.84 & 0.97 & 0.86 \\
\hline 40 & ELA vs $Z_{\text {up }}$ & 0.98 & 0.99 & 0.95 & 0.95 & 0.97 & 0.97 & 0.97 & 0.98 & 0.96 & 0.97 \\
\hline 41 & ELA vs $x$ & -0.51 & -0.46 & 0.15 & -0.07 & 0.28 & -0.28 & -0.14 & 0.03 & -0.19 & 0.02 \\
\hline 42 & Evs $x$ & 0.19 & -0.07 & -0.31 & -0.38 & -0.21 & -0.22 & -0.21 & -0.21 & -0.22 & -0.32 \\
\hline 43 & $Z_{\text {up }}$ vs $Z_{\text {m }}$ & 0.98 & 0.99 & 0.96 & 0.95 & 0.97 & 0.97 & 0.97 & 0.98 & 0.97 & 0.98 \\
\hline 44 & $Z_{\mathrm{up}}$ vs $Z_{\mathrm{t}}$ & 0.96 & 0.87 & 0.86 & 0.69 & 0.92 & 0.80 & 0.92 & 0.78 & 0.89 & 0.81 \\
\hline 45 & $Z_{\mathrm{t}}$ vs $Z_{\mathrm{m}}$ & 0.98 & 0.90 & 0.96 & 0.81 & 0.97 & 0.85 & 0.97 & 0.83 & 0.96 & 0.86 \\
\hline 46 & $S$ vs $x$ & 0.85 & 0.90 & 0.96 & 0.94 & 0.93 & 0.92 & 0.93 & 0.94 & 0.85 & 0.95 \\
\hline 47 & $S$ vs $Z_{\mathrm{t}}$ & -0.55 & -0.51 & -0.37 & -0.42 & -0.42 & -0.47 & -0.34 & -0.32 & -0.26 & -0.28 \\
\hline 48 & $S$ vs $Z_{\text {up }}$ & -0.40 & -0.46 & 0.01 & 0.15 & -0.16 & -0.21 & -0.06 & 0.07 & -0.03 & 0.12 \\
\hline 49 & $S$ vs $Z_{\mathrm{m}}-Z_{\mathrm{t}}$ & 0.75 & 0.60 & 0.64 & 0.67 & 0.65 & 0.62 & 0.66 & 0.70 & 0.54 & 0.73 \\
\hline 50 & $S$ vs $Z_{\text {up }}-Z_{\mathrm{t}}$ & 0.54 & 0.57 & 0.68 & 0.77 & 0.65 & 0.68 & 0.67 & 0.76 & 0.43 & 0.78 \\
\hline 51 & $S$ vs ELA - $Z_{t}$ & 0.67 & 0.49 & 0.72 & 0.76 & 0.68 & 0.61 & 0.68 & 0.70 & 0.43 & 0.72 \\
\hline 52 & $S$ vs $Z_{\mathrm{m}}$ & -0.42 & -0.49 & -0.20 & -0.06 & -0.29 & -0.33 & -0.19 & -0.04 & -0.12 & 0.00 \\
\hline 53 & $S$ vs ELA & -0.45 & 0.53 & -0.19 & -0.06 & -0.29 & -0.35 & -0.19 & -0.04 & -0.17 & -0.05 \\
\hline 54 & $S$ vs $E$ & -0.08 & 0.02 & -0.26 & -0.38 & -0.15 & -0.18 & -0.15 & -0.18 & -0.18 & -0.34 \\
\hline 55 & $S$ vs $b_{\mathrm{n}}$ & -0.53 & -0.09 & 0.28 & 0.21 & -0.04 & -0.03 & -0.02 & 0.02 & -0.12 & -0.13 \\
\hline 56 & $S$ vs $b_{\text {up }}$ & 0.77 & 0.54 & 0.16 & 0.13 & 0.36 & 0.34 & 0.36 & 0.23 & 0.32 & 0.22 \\
\hline 57 & $S$ vs $b_{\mathrm{t}}$ & 0.78 & 0.40 & 0.51 & 0.63 & 0.55 & 0.48 & 0.57 & 0.56 & 0.09 & 0.47 \\
\hline 58 & $S$ vs $b_{\mathrm{n}}-b_{\mathrm{t}}$ & 0.82 & 0.48 & 0.49 & 0.63 & 0.55 & 0.53 & 0.57 & 0.61 & 0.11 & 0.52 \\
\hline 59 & $S$ vs $b_{\text {up }}-b_{\text {n }}$ & 0.55 & 0.36 & 0.29 & 0.19 & 0.38 & 0.25 & 0.38 & 0.26 & 0.30 & 0.27 \\
\hline 60 & $S$ vs $b_{\text {up }}-b_{\mathrm{t}}$ & 0.84 & 0.52 & 0.50 & 0.55 & 0.57 & 0.52 & 0.59 & 0.58 & 0.19 & 0.50 \\
\hline 61 & $x$ vs $Z_{\mathrm{t}}$ & -0.61 & -0.47 & -0.37 & -0.44 & -0.42 & -0.44 & -0.31 & -0.28 & -0.34 & -0.23 \\
\hline 62 & $x$ vs $Z_{\mathrm{m}}$ & -0.48 & -0.42 & -0.15 & -0.06 & -0.26 & -0.26 & -0.13 & 0.03 & -0.12 & 0.08 \\
\hline 63 & $x$ vs $Z_{\text {up }}$ & -0.40 & -0.36 & 0.08 & 0.17 & -0.10 & -0.11 & 0.03 & 0.16 & 0.03 & 0.20 \\
\hline 64 & $x$ vs $Z_{\mathrm{m}}-Z_{\mathrm{t}}$ & 0.79 & 0.76 & 0.79 & 0.72 & 0.72 & 0.72 & 0.75 & 0.79 & 0.80 & 0.81 \\
\hline 65 & $x$ vs $Z_{\text {up }}-Z_{\mathrm{t}}$ & 0.74 & 0.78 & 0.82 & 0.83 & 0.77 & 0.81 & 0.81 & 0.86 & 0.79 & 0.87 \\
\hline 66 & $x$ vs ELA $-Z_{\mathrm{t}}$ & 0.68 & 0.64 & 0.82 & 0.82 & 0.73 & 0.74 & 0.75 & 0.80 & 0.68 & 0.81 \\
\hline
\end{tabular}


3. Mass balance at the head of the glacier. $b_{\text {up }}$ correlates best with length $x(r=0.76)$. In general, $b_{\text {up }}$ correlates well (around 0.6) with all measures of elevation $\left(Z_{\mathrm{m}}\right.$, $\left(Z_{\mathrm{m}}-Z_{\mathrm{t}}\right)$ and $\left.\left(Z_{\text {up }}-Z_{\mathrm{t}}\right)\right)$.

4. ELA. The ELA is best correlated with the mean elevation $Z_{\mathrm{m}}(r=0.99)$. The correlation between the ELA and $Z_{\mathrm{t}}$ and $Z_{\mathrm{up}}$ is also $>0.95$ for all samples.

5. Surface area. $S$ is strongly correlated with many parameters, especially the length $x(r=0.82-0.95$ for all samples) and various mass balances such as $b_{\mathrm{t}}, b_{\mathrm{up}}$, $\left(b_{\text {up }}-b_{\mathrm{t}}\right)$, and $\left(b_{\mathrm{n}}-b_{\mathrm{t}}\right)$ (with $r$ around 0.8 for sample 1). $S$ is somewhat correlated with elevations (e.g. $\left(Z_{\text {up }}-Z_{\mathrm{t}}\right)$ and $\left.\left(Z_{\mathrm{m}}-Z_{\mathrm{t}}\right)\right)$, and is more weakly correlated with the ELA and $Z_{\mathrm{m}}(r \approx 0.4)$. The correlation of $S$ with the activity index $E$ is very weak.

6. Length. $x$ is well correlated with many parameters, particularly $Z_{\mathrm{t}}$ and differences in elevation such as $\left(Z_{\text {up }}-Z_{\mathrm{t}}\right)$. This is expected since $x$ is well correlated with the surface area, which is also well correlated with many other parameters.

\section{DISGUSSION}

Based on experience, simple physical arguments and previous analyses, many of the strong correlations are expected. For example, the correlations between many morphological properties (such as upper and lower elevations, the range in elevation, length and surface area) have obvious physical explanations: the larger a glacier's area, the greater its length (Bahr, 1997); and the higher $Z_{\text {up }}$ (the higher the mountains), the larger the size and length of glaciers. Nevertheless these strong correlations may be helpful for global monitoring because only one of the three parameters (area, length or elevation) is available in many cases.

A similarly reasonable and strong correlation between the ELA and the mean elevation has been suggested (personal communication from A. Ruddel, 1997). When averaged over long time-spans, the ELA is always close to $Z_{\mathrm{m}}$ and will also have a strong correlation with $Z_{\mathrm{t}}$. Likewise, longer glaciers are expected to be strongly correlated with $b_{\text {up }}$ and $b_{\mathrm{t}}$, because the greater length implies a greater range in altitude and a greater span in climate conditions. An obvious reason for some of the weak correlations between the net mass balance and other parameters, such as elevation and area, is that $b_{11} \approx 0$ for all glaciers that are in or nearly in a steady state, regardless of the size of the glacier.

However, many of the correlations are not expected or do not have an immediate physical explanation. For example, the correlations between differences in mass balance $\left(b_{\text {up }}-b_{\mathrm{t}}, b_{\mathrm{n}}-b_{\mathrm{t}}, b_{\mathrm{n}}-b_{\mathrm{up}}\right)$ and any other properties are consistently better than the correlations between simple mass-balance measurements $\left(b_{\mathrm{up}}, b_{\mathrm{t}}, b_{\mathrm{n}}\right)$ and these other properties. In fact, the good correlation between these differences in mass balance and glacier length, surface area and range in altitude $\left(Z_{\text {up }}-Z_{t}\right)$ suggests that these parameters would be good for global glacier monitoring.

On the other hand, there is a very weak correlation between the ELA and glacier mass balance for all samples. On individual glaciers, the ELA is known to correlate very strongly with $b_{\mathrm{n}}(G M B, 1991,1993,1994,1996)$. However, the global spatial correlation between net mass balances is very poor (Dyurgerov, 1994; Cogley and others, 1995) because glaciers occur in a wide variety of climatic zones from polar to temperate. We expect, therefore, that the ELA would also have a poor spatial correlation, and it is not too surprising that the correlation between the net mass balance and the ELA is poor.

Similar arguments suggest that the activity index, $E$, would be a poor tool for global glacier monitoring. Likewise, the very weak correlation between $b_{\mathrm{n}}$ and $b_{\mathrm{t}}$ for all samples prevents the net balance from being replaced by simpler measurements of the balance at the terminus. Measuring $b_{\mathrm{t}}$ (and one or two stakes in the vicinity of the ELA) is not a good strategy for global mass-balance monitoring (Haeberli, 1995).

The simple valley glaciers (sample 1) frequently have stronger correlations than other samples. The reasons for this are unclear, although sample 1 is the most homogeneous in size and type. However, in several cases, the correlations in sample 5 (all glaciers) are at least as large as the correlations in other samples. This is true, in particular, for powerlaw correlations and for parameters that are common in routine glaciological work (e.g. surface area, length, ranges in elevation and ranges in mass balance such as $b_{\text {up }}-b_{\mathrm{n}}$ and $b_{\mathrm{n}}-b_{\mathrm{t}}$ ). The global properties of such parameters may be observed and studied without differentiation by groups or samples.

\section{CONCLUSIONS AND RECOMMENDATIONS}

Net mass balance is typically used to monitor, understand and predict fluctuations in glacier volume, size and length. This relatively difficult-to-measure property $\left(b_{\mathrm{n}}\right)$ might be replaced by other parameters (e.g. $S, x, Z_{\text {up }}, Z_{\mathrm{m}}, Z_{\mathrm{t}}$, ELA, $E, b_{\mathrm{t}}$ and $\left.b_{\mathrm{up}}\right)$, as long as the new parameters are well correlated with $b_{\mathrm{n}}$. Using a substantially larger dataset than in previous studies, we have calculated a large number of correlations to demonstrate which glacier properties might be useful as substitutes and which other properties would be less helpful (Table 2).

Most notably, correlations between net mass balance $b_{\mathrm{n}}$ and the terminus balance $b_{\mathrm{t}}$ are poor. Likewise the correlation between $b_{\mathrm{n}}$ and $b_{\mathrm{up}}$ is poor. Thus, despite previous suggestions, neither $b_{\mathrm{t}}$ nor $b_{\text {up }}$ should be used as a replacement for $b_{\mathrm{n}}$ in global monitoring strategies. On the other hand, the terminus balance is well correlated with $\left(Z_{\mathrm{m}}-Z_{\mathrm{t}}\right)$. Because $b_{\mathrm{t}}, Z_{\mathrm{m}}$ and $Z_{\mathrm{t}}$ are easy to measure in the field and to derive from maps or remotely acquired images (in contrast to $b_{\mathrm{n}}$ or the ELA), this relationship could be helpful in estimating the maximum ablation rate and total meltwater production over large regions. Ranges in mass balance (e.g. $b_{\text {up }}-b_{\mathrm{n}}, b_{\mathrm{n}}-b_{\mathrm{t}}$ and $\left.b_{\text {up }}-b_{\mathrm{t}}\right)$ are also well correlated with many other parameters (e.g. ranges in elevation) and are usually better correlated than $b_{\mathrm{up}}, b_{\mathrm{n}}$ or $b_{\mathrm{t}}$. Thus, the ranges in mass balance could be particularly useful in any of the global monitoring programs which have previously used only the direct measurements of mass balance $\left(b_{\mathrm{up}}, b_{\mathrm{n}}\right.$ or $\left.b_{\mathrm{t}}\right)$.

The correlations between the activity index and mass balances $\left(b_{\mathrm{up}}, b_{\mathrm{n}}\right.$ and $\left.b_{\mathrm{t}}\right)$ are weak. This implies that the activity index is a unique property of individual glaciers and most likely reflects local and/or regional climate and topography, rather than global climate. Similarly, the correlations between ELAs and glacier mass balances $\left(b_{\mathrm{up}}, b_{\mathrm{n}}\right.$ and $b_{\mathrm{t}}$ ) are very weak. If necessary, though, the ELA may be 
replaced by $Z_{\mathrm{m}}, Z_{\mathrm{t}}$ or $Z_{\mathrm{up}}$, as it is strongly correlated with each of these. This gives a nice technique for replacing a harder-to-measure climatically sensitive parameter with an easily measured altitude

Although, in many cases, the correlations between different glacier parameters are poor (Table 2), there are enough strong relationships to suggest that global massbalance monitoring can be based on a relatively small subset of glacier properties. Some of these parameters (e.g. $\left.Z_{\mathrm{m}}, Z_{\mathrm{t}}, Z_{\mathrm{up}}, S, x\right)$ may be extracted from glacier inventories or determined from remotely sensed images (e.g. the difference between the ELA and $Z_{\mathrm{m}}, Z_{\mathrm{t}}, Z_{\text {up }}$ ). Other properties (e.g. $b_{\mathrm{t}}, b_{\mathrm{up}}, b_{\mathrm{n}}$ ) have to be measured in the field on benchmark glaciers or calculated in models (e.g. Tangborn, 1980; Oerlemans, 1993). The relationships (suggested by the strong correlations in Table 2) between these easy- and hard-tomeasure parameters can help estimate glacier mass balances in entire mountain ranges or on a global scale.

\section{ACKNOWLEDGEMENTS}

We thank M. F. Meier, R. LeB. Hooke, and W. Tangborn for clarification of many points in the text. This study was supported by U.S. National Science Foundation grants OPP9530782 and OPP-9634289.

\section{REFERENCES}

Bahr, D. B. 1997. Width and length scaling of glaciers. F. Glaciol., 43(145), $557-562$.

Blatter, H. and G. Kappenberger. 1988. Mass balance and thermal regime of Laika ice cap, Coburg Island, N.W.T., Canada. f. Glaciol., 34(116), $102-110$.

Chen Jiyang. 1991. Changes of alpine climate and glacier water resources. Zürcher Geogr. Schr. 46.

Cogley, J. G., W. P. Adams, M. A. Ecclestone, F. Jung-Rothenhäusler and C. S. L. Ommanney. 1995. Mass balance of Axel Heiberg Island glaciers, 1960-1991: a reassessment and discussion. Saskatoon, Sask., Environment Canada. National Hydrology Research Institute. (NHRI Science Report 6.)

Dyurgerov, M. B. 1988. Metodicheskiye osnovy i programma nablyudeniy za kolebaniyami vneshnego massoobmena i balansa massy lednikov [Systematic methodological principles and a programme of observations of the fluctuations of external mass exchange and mass balance of glaciers]. Mater. Glyatsiol. Issled. 64, 153-163.

Dyurgerov, M. B. 1993. Monitoring balansa massy gornykh lednikov [Monitoring the mass balance of mountain glaciers ]. Moscow, Nauka.

Dyurgerov, M. B. 1994. Mass balance fluctuations and their contribution to sea level changes. Moscow, Russian Academy of Science. Institute of Geography; Washington, DC, U.S. Department of State.

Dyurgerov, M. B. and M. F. Meier. 1997. Mass balance of mountain and subpolar glaciers: a new global assessment for 1961-1990. Arct. Alp. Res., 29 (4), 379-391.

Dyurgerov, M. B., V. N. Uvarov and T. E. Kostjashkina. 1996. Mass balance and runoff of Tuyuksu glacier and the north slope of the Zailiyskiy Alatau Range, Tien Shan. Z. Gletscherkd. Glazialgeol., 32, Part 2, 41-54.

Fountain, A. G., R. M. Krimmel and D. C. Trabant. 1997. A strategy for monitoring glaciers. U.S. Geol. Surv. Circ. 1132.

Funk, M., R. Morelli and W. Stahel. 1997. Mass balance of Griesgletscher 1961-1994: different methods of determination. Z. Gletscherkd. Glazialgeol., 33(1), 1996, 41-55.

Galakhov, V. P. and 7 others. 1987. Ledniki Aktru, Altay [Aktru glaciers, Altay]. Leningrad, Hydrometeoizdat.

Glazyrin, G. Ye., G. M. Kamniansky and F. I. Pertziger. 1993. Rezhim lednika Abramova [Regime of the Abramov Glacier]. St. Petersburg, Gidrometeoizdat.

Haeberli, W., comp. 1985. Fluctuations of glaciers 1975-1980 (Vol. IV). Paris, International Commission on Snow and Ice of the International Association of Hydrological Sciences/UNESCO.

Haeberli, W. 1995. Glacier fluctuations and climate change detectionoperational elements of a worldwide monitoring strategy. WMO Bull., $44(1), 23-31$.
Hacberli, W. and E. Herren, eds. 1991. Glacier Mass Balance Bulletin. Bulletin No.1 (1988 1989). Zürich, IAHS (ICSI), World Glacier Monitoring Service; Nairobi, UNEP; Paris, UNESCO.

Haeberli, W. and M. Hoelzle, comps. 1993. Fluctuations of glaciers 19851990 (Vol. VI). Wallingford, Oxon, IAHS Press; Nairobi, UNEP; Paris, UNESCO.

Haeberli, W. and P. Müller, comps. 1988. Fluctuations of glaciers 1980-1985 (Vol. V). Wallingford, Oxon, IAHS Press; Nairobi, UNEP; Paris, UNESCO.

Haeberli, W., E. Herren and M. Hoelzle, eds. 1993. Glacier Mass Balance Bulletin. Bulletin No.2 (1990-1991). Zürich, IAHS (ICSI), World Glacier Monitoring Service; Nairobi, UNEP; Paris, UNESCO.

Haeberli, W., M. Hoelzle and H. Bösch, eds. 1994. Glacier Mass Balance Bulletin. Bulletin. No.3 (1992-1993). Zürich, IAHS (ICSI), World Glacier Monitoring Service; Nairobi, UNEP; Paris, UNESCO.

Haeberli, W., M. Hoelzle and S. Suter, eds. 1996. Glacier Mass Balance Bulletin. Bulletin No.4 (1994-1995). Zürich, IAHS (ICSI), World Glacier Monitoring Service; Nairobi, UNEP; Paris, UNESCO.

Hastenrath, S. 1991. Glaciological studies on Mount Kenya 1971-83-91. Madison, WI, University of Wisconsin. Department of Meteorology.

Holmlund, P., W. Karlén and H. Grudd. 1996. Fifty years of mass balance and glacier front observations at the Tarfala Research Station. Geogr. Ann., 78A (2-3), 105-114.

Jóhannesson, T., C. Raymond and E. D. Waddington. 1989. Time-scale for adjustment of glaciers to changes in mass balance. 7. Glaciol., 35(121), 355-369.

Kasser, P., comp. 1973. Fluctuations of glaciers 1965-1970 [Vol. II]. Paris, International Commission on Snow and Ice of the International Association of Hydrological Sciences/UNESCO.

Krenke, A. N. and V. M. Menshutin. 1987. Calculation of mass balance of glaciers by remote-sensing imagery using similarity of accumulation and ablation isoline patterns. f. Glaciol., 33 (115), 363-368.

Krenke, A. N. and 19 others. 1988. Lednik Marukh (Zapadniy Kavkaz) (Marukh Glacier, western Caucasus]. Leningrad, Gidrometeoizdat.

Krimmel, R. M. 1995. Water, ice, and meteorological measurements at South Cascade Glacier, Washington, 1994 balance year. U.S. Geol. Surv. Water-Resour. Invest. Rep. 95-4162.

Makarevich, K. G., Ye. N. Vilesov, R. G. Golovkova, T. Ya. Demisova and P. F. Shabanov. 1984. Ledniki Tuyuksu (Severnyy Tyan-Shan) [The Tuyuksu glaciers (northern Tien Shan) ]. Leningrad, Hydrometeoizdat.

Meier, M. F. 1965. Glaciers and climate. In Wright, H. E., Jr and D. G. Frey, eds. The Quaternary of the United States. Princeton, NJ, Princeton University Press, 795-805.

Meier, M. F. 1993. Ice, climate, and sea level: do we know what is happening? In Peltier, W. R., ed. Ice in the climate system. Berlin, etc., SpringerVerlag, 141-160. (NATO ASI Series I: Global Environmental Change 12.)

Meier, M. F. and A. Post. 1987. Fast tidewater glaciers. J. Geophys. Res., 92(B9), $9051-9058$.

Mikhalenko, V. N., M. B. Dyurgerov and Liu Chaohai. 1995. Balans massy otdel'nikh lednikov $\mathrm{i}$ ikh basseiynov [The mass balance of individual glaciers and their basins]. In Dyurgerov, M. B., Liu Chaohai and Xie Zichu, eds. Oledeneniye Tyan'-Shanya [Tien Shan glaciers]. Moscow, Vsesoyuznyy Institut Nauchnoy i Tekhnicheskoy Informatsii (VINITI), 79-100.

Moser, H., H. Escher-Vetter, H. Oerter, O. Reinwarth and D. Zunke. 1986. Abfluss in und von Gletschern. München, Gesellschaft für Strahlen- und Umweltforschung. (GSF Bericht 41/86.)

Müller, F., comp. 1977. Fluctuations of glaciers 1970-1975 (Vol. III). Paris, International Commission on Snow and Ice of the International Association of Hydrological Sciences/UNESCO.

Narozhnyy, Yu. K. 1991. Balans massy lednikov Altaya i ikh klimaticheskaya obuslovlennost' [The mass balance of the Altay glaciers and their climatic causes]. Mater. Glyatsiol. Issled. 72, 107-116.

Oerlemans, J. 1993. Modelling of glacier mass balance. In Peltier, W. R., ed. Ice in the climate system. Berlin, etc., Springer-Verlag, 101-116. (NATO ASI Series I: Global Environmental Change 12.)

Ostrem, G. and M. Brugman. 1991. Glacier mass-balance measurements. A manual for field and office work. Saskatoon, Sask., Environment Canada. National Hydrology Research Institute. (NHRI Science Report 4.)

Pertziger, F. I., ed. 1996. Abramov glacier data reference book: climate, runoff, mass balance. München, Technical University.

Tangborn, W. 1980. Two models for estimating climate-glacier relationships in the North Cascades, Washington, U.S.A. J. Glaciol., 25 (91), 3-21.

Vinogradov, V. N. and Ya. D. Murav'yev. 1992. Lednik Kozelskiy (Avachinskaya gruppa vulcanov) [Kozelskiy Glacier (Avachinsky volcano group)]. St. Petersburg, Gidrometeoizdat.

Voloshina, A.P. 1987. Nekotoryye itogi issledovaniy balansa massy lednikov Polyarnogo Urala [Some results of glacier mass-balance studies in the polar Urals]. Mater. Glyatsiol. Issled. 61, 44-51. 